\title{
Familiáris myelodysplasiás szindrómában szenvedő család genomikus kópiaszám- változásainak vizsgálata multiplex ligatiofüggő szondaamplifikációval
}

\author{
Kotmayer Lili ${ }^{1}$, Kiss Richárd ${ }^{1}$, Király Péter Attila ${ }^{2}$, Csomor Judit ${ }^{1}$, \\ Kállay Krisztián ${ }^{3}$, Alpár Donát ${ }^{1}$, Bödör Csaba ${ }^{1, @ ~}$ \\ ${ }^{1}$ Semmelweis Egyetem, I. sz. Patológiai és Kísérleti Rákkutató Intézet, \\ MTA-SE Lendület Molekuláris Onkohematológia Kutatócsoport, Budapest \\ ${ }^{2}$ Semmelweis Egyetem, I. sz. Belgyógyászati Klinika, Budapest \\ ${ }^{3}$ Dél-pesti Centrumkórház - Országos Hematológiai és Infektológiai Intézet, \\ Gyermekhematológiai és Őssejt-transzplantációs Osztály, Budapest
}

\begin{abstract}
A familiáris myelodysplasiás szindróma (FMDS) egy ritka, klinikailag rendkívül heterogén megjelenésű örökletes kórkép. Az FMDS hátterében általában prediszpozíciós szindrómák állnak, melyeket különböző géneket érintő autoszomális dominánsan öröklődő mutációk okoznak. Az eddig leírt hajlamosító variánsok túlnyomó része pontmutáció vagy néhány bázispárra kiterjedő deléció, azonban a betegség genetikai komplexitását jellemzi, hogy olykor DNSkópiaszám-változások is előfordulnak. Tanulmányunkban klinikai adatok alapján diagnosztizált familiáris myelodysplasiás szindrómában szenvedő testvérpár és szüleik mintáit vizsgáltuk a kiegyensúlyozatlan genomikus abnormalitások detektálására is alkalmas multiplex ligatiofüggő szondaamplifikációs módszerrel. A vizsgálat során mindkét gyermek és az édesapa DNS-mintájában a TERC gént érintő részleges deléciót azonosítottunk. Az általunk azonosított genetikai eltérés alapján a vizsgált eset az ún. „telomere biology disorder” (TBD) prediszpozíciós szindrómák közé tartozik. Az öröklött csontvelö-elégtelenséggel járó kórkép családon belüli halmozódása felhívja a figyelmet a betegségben előforduló germline kópiaszám-változások vizsgálatának, valamint a részletes családi anamnézis felvételének fontosságára. A genetikai háttér tisztázásának a további terápiás döntések meghozatalában is fontos szerepe van, mivel a gyermekkori MDS hátterében álló prediszpozíciós szindrómák a rájuk jellemző fenotípus nélkül is jelen lehetnek a vizsgált betegekben, befolyásolva az MDS kezelésének kimenetelét.
\end{abstract}

Kulcsszavak: familiáris MDS, MLPA, TERC, kópiaszám-változás

\section{Screening for genomic copy number alterations in a family suffering from myelodysplastic syndrome using multiplex ligation-dependent probe amplification}

\begin{abstract}
Familial myelodysplastic syndrome is a rare heritable disease with a clinically heterogeneous manifestation. The disease usually arises from predisposition syndromes associated with germline mutations in various genes with autosomal dominant inheritance, however these variants do not always lead to overt disease. The predisposing genetic alterations described in these cases are mostly point mutations or smaller deletions affecting few base-pairs, but DNA copy number alterations also occur, highlighting the genomic heterogeneity of this disease. In this study, a pedigree with two siblings and their parents diagnosed with myelodysplastic syndrome, was analysed using multiplex ligationdependent probe amplification, enabling us to detect instances of unbalanced DNA rearrangements. We identified a partial deletion within the TERC gene in samples of the two siblings, with the same aberration also detected in the father's DNA sample. Multiple occurrence of this genetic abnormality in the family underlines the importance of screening for DNA copy number alterations in patients with myelodysplastic syndrome as well as assembling a properly detailed anamnesis for the whole family. The genetic variant and its recognition also influence the further thera-
\end{abstract}

@ Levelezési cím: Dr. Bödör Csaba, Semmelweis Egyetem, I. sz. Patológiai és Kísérleti Rákkutató Intézet, 1085 Budapest, Üllői út 26.; Tel.: +36-1-215-7300/54462; E-mail: bodor.csaba1@med.semmelweis-univ.hu 
peutic management of the family, as the predisposition syndromes can be present in some cases, even without their specific phenotype.

Keywords: familial MDS, TERC, CNA, MLPA

(Beérkezett: 2018. november 1.; elfogadva: 2018. december 4.)

\section{Rövidítések}

FMDS = familiáris myelodysplasiás szindróma; TBD = „telomere biology disorder"; MLPA = multiplex ligatiofüggő szondaamplifikáció; $\mathrm{MDS}=$ myelodysplasiás szindróma; $\mathrm{AML}=$ akut myeloid leukémia; TERC = telomeráz RNS komponens gén; FISH = fluoreszcens in situ hibridizáció; $\mathrm{DC}=$ dyskeratosis congenita; NGS = új generációs szekvenálás (next generation sequencing)

A myelodysplasiás szindróma (MDS) csontvelői multipotens hematopoetikus őssejteket érintő daganatos megbetegedés, mely az esetek mintegy $30 \%$-ában akut myeloid leukémiába (AML) transzformálódik [1]. A genetikailag instabil őssejtklónból kiinduló myeloid sejtvonalak jelentős károsodást szenvednek, ezért a perifériás vérben mindig észlelhető egy vagy több sejtvonalat érintő citopenia. A fö klinikai tünetek az anaemia, a thrombocytaszám csökkenése miatt előforduló vérzések és a granulocyták hiánya miatt bekövetkező spontán fertőzések. A csontvelő változatos megjelenésű, a megbetegedések nagyobb részét kitevő felnőttkori esetekre a hypercelluláris vagy normocelluláris, a gyerekkori esetekre a hypocelluláris csontvelő jellemző $[2,3]$.

A myelodysplasiás szindróma általában sporadikus előfordulású és a betegek több mint fele 50 évnél idősebb. $\mathrm{Az}$ MDS esetek kevesebb mint 7\%-át adó gyerekkori MDS de novo (primer) és szekunder csoportokra osztható $[4,5]$. A gyermekkori de novo megbetegedések mintegy felét az általunk is vizsgált, családi halmozódást mutató hypocelluláris MDS (WHO: refractory cytopenia of childhood) teszi ki [1].

A genetikai vizsgálatok fejlődésével a sporadikus megbetegedések egyre nagyobb részéről derül ki, hogy azok hátterében prediszpozíciós szindrómák állnak. Ezek a herediter kórképek autoszomális dominánsan öröklődő mutációk eredményeképpen alakulnak ki, és egész életen át növelik az MDS/AML kialakulásának rizikóját [4, 6]. Ezeknek az öröklődő genetikai eltéréseknek az esetében inkomplett penetrancia is elöfordulhat, azaz nem mindig észlelhető a prediszpozíciós szindrómákra jellemző klinikai megjelenés, így az MDS családi halmozódása esetén különösen fontos a részletes családi anamnézis, ideértve a genetikai vizsgálatokat is.

A prediszpozíciós szindrómáknak az érintett gének alapján jelenleg számos típusa ismert, amelyek a különböző szindrómákra specifikus fenotípussal bírnak: 1) telo- meropathiák a $D K C 1, T E R C$ és TERT gének mutációjával; 2) familiáris vérlemezke-funkciózavar a RUNX1 gén érintettségével; 3) a GATA2-mutációt hordozó MDS/ AML kórképek; 4) az ETV6-és az ANKRD26-mutációk miatt kialakuló thrombocytopeniák; 5) aplasticus anaemia az SRP72 mutációjával; 6) familiáris AML a $D D X 41$ gén érintettségével; 7) a $F A N C$ gének mutációi miatt kialakuló Fanconi-anaemia [4, 7, 8]. A prediszpozíciós szindrómákat okozó germline eltérésekben egyre több gén érintettségét írják le, így a molekuláris vizsgálati módszerek fejlődésével az MDS hátterében álló hajlamosító genetikai variáns egyre gyakrabban kerül felismerésre [9, 10]. A myelodysplasiás szindrómában szenvedő betegek 8090\%-a hordoz valamilyen szomatikus genetikai eltérést is, így a felsoroltakon kívül gyakoriak még a $S F 3 B 1, T E T 2$, $A S X L 1$, TP53, U2AF1, DNMT3A és EZH2 gének szomatikus mutációi is [11-13]. Ezek a szomatikus variánsok indokolják a molekuláris mechanizmusok további feltérképezését a familiáris MDS esetekben, mivel a szekunder mutációk a germline-variánsok mellett triggerként kiválthatják a betegség manifesztációját [14]. Bár a prediszpozíciós szindrómáknak sokféle típusa ismert, és a felsorolt szomatikus mutációk mellett a betegek jelentős részénél magyarázatként szolgálnak a betegség megjelenésére és expresszivitására, a családi halmozódást mutató esetek mintegy harmadában a hajlamosító genetikai variáns továbbra is ismeretlen. Ezekben az esetekben indokolt lehet az MDS komplex genetikai hátterének további feltérképezése más, a standard diagnosztikai módszerektől eltérő molekuláris vizsgálatokkal.

A familiáris MDS genetikai hátterének feltérképezésében az eddig azonosított pontmutációk és más kiegyensúlyozott aberrációk vizsgálatán kívül a DNS-kópiaszámváltozással járó eltérések vizsgálatára is szükség van. A multiplex ligatiofüggő szondaamplifikációval (MLPA) ilyen, a betegségben jelenlévő kiegyensúlyozatlan genetikai változások, valamint néhány, szintén a familiáris MDSre specifikus pontmutáció detektálható [15-21]. A módszer során adott genomikus lókuszokra specifikus hibridizációs próbák (szondák) amplifikációja történik polimeráz láncreakció (PCR) használatával, majd fluoreszcens kapilláris elektroforézist alkalmazva méret szerint elkülönítjük a keletkező amplifikációs termékeket, meghatározzuk azok mennyiségét és az eredmények referencialókuszokról keletkezett termék mennyiségéhez viszonyítva relatív kópiaszámot számolunk. Amennyiben a vizsgált DNS-szakaszról származó PCR-termékek relatív 
mennyisége a reakcióelegyen belül magasabb, mint a referenciakópiáké, kópiaszámnyerésről vagy amplifikációról, ha kisebb, kópiaszámvesztésről vagy delécióról beszélünk [22].

Jelen vizsgálatunk célja a betegségre hajlamosító genetikai variáns feltárása volt MLPA módszerrel egy olyan családi halmozódást mutató MDS esetben, ahol korábban valamennyi ismert mutáció (GATA2, RUNX1, ETV6, ANKRD26, TERC, TERT, CEBPA) vizsgálata negatív eredménnyel zárult.

\section{Módszerek}

Vizsgálatunkhoz a Dél-pesti Centrumkórház - Országos Hematológiai és Infektológiai Intézetben kezelt, familiáris myelodysplasiás szindrómában szenvedő család mintáit használtuk (\#1-4), akik közül a két gyermek (\#3-4) esetében már előzetesen ismert volt a kórkép. A családfát az 1. ábra mutatja be.

A családtagok mintáiban rutin diagnosztikai eljárásokkal azonosítható eltérést nem detektáltunk. Mivel a betegség családon belüli halmozódása familiáris eredetre utalt, elvégeztük az intézetünkben familiáris MDS esetekben diagnosztikai céllal vizsgált gének (GATA2, RUNX1, CEBPA, ETV6, ANKRD26, SRP72, DDX4) mutációanalízisét. A vizsgálatok során nem találtunk olyan genetikai variánst, amely hajlamosító tényezőként elősegítette volna a betegség megjelenését a két gyermek esetében. A néhány bázispárra kiterjedő deléciók és pontmutációk

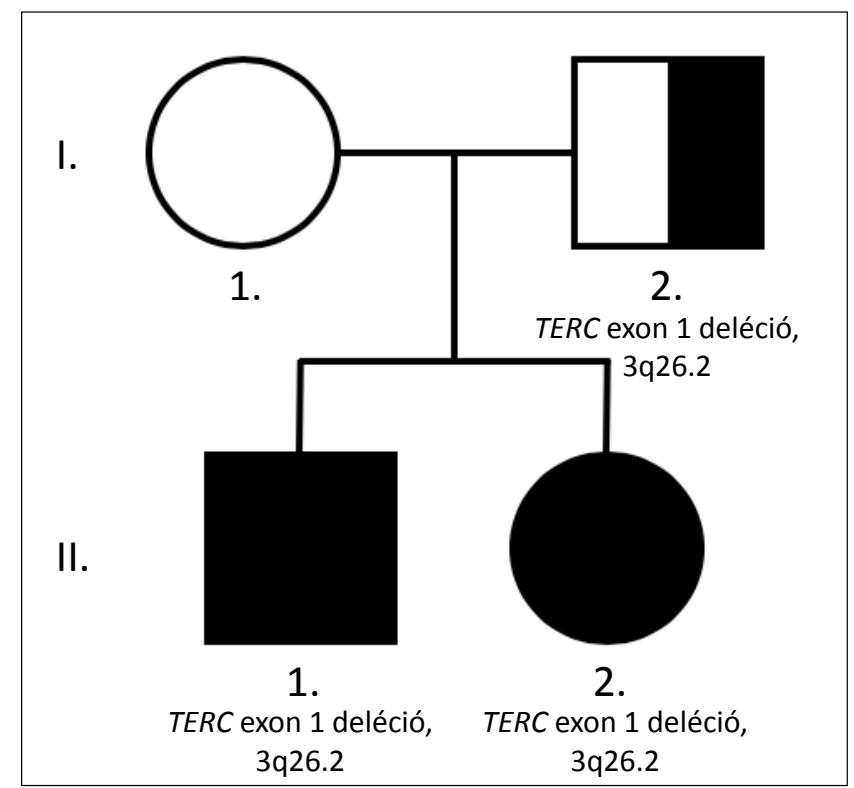

1. ábra. A vizsgált család családfája az azonosított $T E R C-1$ deléció, (del3q), és a familiáris MDS megjelenésének ábrázolásával. $\mathrm{Az}$ anya mintájában (I.1) nem találtunk a betegségre specifikus, eltérést (fehér kör). Az apa (I.2) a monoallélikus TERC-1 deléció hordozója, az ő esetében a betegség nem manifesztálódott (osztott négyzet). A gyermekek (II.1 és II.2 egyének) mindketten hordozói a TERC-1 deléciónak és mindketten familiáris myelodysplasiás szindrómában szenvednek (fekete négyzet és fekete kör) mellett MDS-ben kópiaszám-eltéréssel járó genetikai eltérések is ismertek, így ezek vizsgálatát is elvégeztük a családtagok DNS-mintáin a fentebb ismertetett MLPA módszer alkalmazásával.

Az MLPA reakcióhoz használt DNS-mintákat EDTAval antikoagulált perifériás vérből és csontvelőből nyert sejtekből vontuk ki. A sejtekből történő DNS-izolálást High Pure PCR Template Preparation Kit-tel (Roche) végeztük a gyártó utasításainak megfelelően. Negatív kontrollként olyan DNS-mintákat használtunk, amelyek nem hordoztak ismert klonális malignus megbetegedést. A familiáris MDS-re specifikus MLPA reakcióban vizsgált pontmutációk pozitív kontrolljaként a gyártó által ajánlott GATA2 (c.1192C>T, c.1061C>T) és TERT (c.3184G $<$ A) mutációkat hordozó SD070 Binning DNA-t használtuk. A familiáris MDS-vizsgálatához a SALSA MLPA P437-B1 szondakeveréket használtuk, amely 42 célrégióban történő DNS-kópiaszám-változás, valamint 3 pontmutáció specifikus detektálására alkalmas. A szondakeveréket a gyártó (MRC-Holland, Amszterdam, Hollandia) bocsátotta rendelkezésünkre, és részletes összetételét az 1. táblázat tartalmazza. A PCR reakció során keletkezett amplifikációs termékek méret szerinti szeparálásához ABI 3500 (Thermo Fisher) kapilláris elektroforézis készüléket használtunk. Az elektroferogramok analízisét Coffalyzer.Net (www.mlpa.com) szoftverrel végeztük. A vizsgált célrégiókhoz hibridizáló szondák amplifikációs termékeinek mennyiségét kétlépcsős, mintán belüli (referencia szondákhoz viszonyított), valamint referencia mintákkal szembeni normalizáció révén határoztuk meg. Amennyiben az így létrehozott relatív kópiaszám 1,3-nál magasabbnak bizonyult, többletet vagy amplifikációt dokumentáltunk a vizsgált genomikus szakaszon, amennyiben pedig 0,7-nél alacsonyabb értéket vett fel, deléciót interpretáltunk.

\section{Esetismertetés}

A jelenleg 16 éves fiú és 12 éves lány 2014 óta áll gondozás alatt három sejtsoros citopeniával. Jellemző vérkép leleteik: abszolút neutrofil szám 0,5-1 G/1, hemoglobin 90100 g/l, thrombocyta 50 G/l. Prediszpozíciós szindrómában jellemzően előforduló tüneteik nincsenek, súlyos fertőzéseik nincsenek, a vérszegénységet tolerálják. Vérzéseik nincsenek, vérkészítményt sosem kaptak. A referencia patológia központ (Cs. J.) évente végez csontvelővizsgálatot a gondozó központ kérésére. A gyermekek mind a négy biopsziás mintája refrakter citopenia jellegzetes képét mutatta, a diagnózis a klinikummal együtt gyermekkori hypocelluláris MDS volt. A szövettani kép a klinikummal kiegészítve hypocelluláris gyermekkori myelodyplasiás szindróma diagnózisának felelt meg (2. ábra). A szülőkre kiterjesztett vizsgálat során a 40 éves édesapa családi anamnézisében nem találtunk a felmenőit érintő daganatos megbetegedést.

Áramlási citometriával, kariotipizálással és FISH-vizsgálatokkal kóros eltérés a gyermekekben nem került azo- 
1. táblázat. SALSA MLPA P437-B1 Familial MDS/AML szondakeverék

\begin{tabular}{|c|c|c|c|c|c|c|c|}
\hline Vizsgált gén & Vizsgált exon & $\begin{array}{l}\text { Kromoszóma- } \\
\text { pozíció }\end{array}$ & $\begin{array}{l}\text { Szondahossz } \\
\text { (bázispár) }\end{array}$ & Vizsgált gén & Vizsgált exon & $\begin{array}{l}\text { Kromoszóma- } \\
\text { pozíció }\end{array}$ & $\begin{array}{l}\text { Szondahossz } \\
\text { (bázispár) }\end{array}$ \\
\hline GATA2 & 8 & $3 q 21.3$ & 246 & TERT & 16 & $5 \mathrm{p} 15.33$ & 395 \\
\hline \multirow[t]{3}{*}{ GATA2 } & 8 & $3 q 21.3$ & 168 & TERT & 15 & $5 \mathrm{p} 15.33$ & 148 \\
\hline & c. $1192 \mathrm{C}>\mathrm{T}$ & & & $T E R T$ & 15 & $5 \mathrm{p} 15.33$ & 200 \\
\hline & (p.R398W) & & & & c. $3184 \mathrm{G}>\mathrm{A}$ & & \\
\hline GATA2 & 7 & $3 q 21.3$ & 276 & & (p.A1062) & & \\
\hline \multirow[t]{3}{*}{ GATA2 } & 7 & $3 q 21.3$ & 190 & TERT & 14 & $5 \mathrm{p} 15.33$ & 469 \\
\hline & c. $1061 \mathrm{C}>\mathrm{T}$ & & & $T E R T$ & 13 & $5 \mathrm{p} 15.33$ & 366 \\
\hline & (p.T354M) • & & & $T E R T$ & 12 & $5 \mathrm{p} 15.33$ & 229 \\
\hline GATA2 & intron 6 & $3 q 21.3$ & 445 & TERT & 11 & $5 p 15.33$ & 331 \\
\hline GATA2 & 6 & $3 q 21.3$ & 142 & $T E R T$ & 10 & $5 \mathrm{p} 15.33$ & 418 \\
\hline GATA2 & 5 & $3 q 21.3$ & 409 & TERT & 9 & $5 \mathrm{p} 15.33$ & 224 \\
\hline GATA2 & 4 & $3 q 21.3$ & 355 & $T E R T$ & 8 & $5 \mathrm{p} 15.33$ & 475 \\
\hline GATA2 & 3 & $3 q 21.3$ & 219 & TERT & 7 & $5 \mathrm{p} 15.33$ & 195 \\
\hline GATA2 & 2 & $3 q 21.3$ & 346 & $T E R T$ & 6 & $5 \mathrm{p} 15.33$ & 207 \\
\hline GATA2 & 1 & $3 q 21.3$ & 316 & TERT & 5 & $5 \mathrm{p} 15.33$ & 454 \\
\hline TERC & 1 & $3 q 26.2$ & 270 & $T E R T$ & 4 & $5 \mathrm{p} 15.33$ & 258 \\
\hline TERC & 1 & $3 q 26.2$ & 130 & $T E R T$ & 3 & $5 \mathrm{p} 15.33$ & 296 \\
\hline TERC & 1 & $3 q 26.2$ & 373 & $T E R T$ & 2 & $5 \mathrm{p} 15.33$ & 161 \\
\hline$T E R C$ & 1 & $3 q 26.2$ & 489 & $T E R T$ & 1 & $5 \mathrm{p} 15.33$ & 178 \\
\hline CEBPA & 1 & $19 q 13.11$ & 265 & $R U N X 1$ & $9(10)$ & $21 \mathrm{q} 22.12$ & 324 \\
\hline CEBPA & 1 & $19 q 13.11$ & 136 & $R U N X 1$ & $8(9)$ & $21 q 22.12$ & 301 \\
\hline CEBPA & 1 & $19 q 13.11$ & 309 & $R U N X 1$ & intron $7(\mathrm{ex} 8)$ & $21 \mathrm{q} 22.12$ & 157 \\
\hline$F A F 1^{*}$ & & $1 \mathrm{p} 32$ & 288 & $R U N X 1$ & 7 & $21 q 22.12$ & 388 \\
\hline$C A C N A 1 S^{*}$ & & $1 q 32$ & 173 & $R U N X 1$ & 6 & $21 q 22.12$ & 439 \\
\hline$D Y S F^{*}$ & & $2 \mathrm{p} 13$ & 497 & $R U N X 1$ & 5 & $21 \mathrm{q} 22.12$ & 425 \\
\hline$A C V R 2 A^{*}$ & & $2 q 23$ & 431 & $R U N X 1$ & $4(4 b)$ & $21 \mathrm{q} 22.12$ & 241 \\
\hline$A T P 8 A 1^{*}$ & & $4 \mathrm{p} 13$ & 124 & $R U N X 1$ & 3 & $21 \mathrm{q} 22.12$ & 360 \\
\hline$P K H D 1^{*}$ & & $6 \mathrm{p} 12$ & 253 & $R U N X 1$ & 2 & $21 q 22.12$ & 283 \\
\hline PCSK5* & & $9 \mathrm{q} 21$ & 184 & $R U N X 1$ & 1 & $21 \mathrm{q} 22.12$ & 212 \\
\hline$S T X B P 1^{*}$ & & $9 q 34$ & 381 & $S P G 11^{*}$ & & $15 \mathrm{q} 21$ & 481 \\
\hline$U P F 2^{*}$ & & $10 \mathrm{p} 14$ & 402 & $M C 4 R^{*}$ & & $18 \mathrm{q} 21$ & 233 \\
\hline$S M P D 1^{*}$ & & $11 \mathrm{p} 15$ & 505 & $S A M H D 1^{*}$ & & $20 \mathrm{q} 11$ & 460 \\
\hline PSEN1* & & $14 \mathrm{q} 24$ & 337 & & & & \\
\hline
\end{tabular}

* referenciaszonda

- pontmutációt jelölő eltérések

nosításra. A háttérben álló esetleges vírusfertőzéseket kizártuk. A gyermekek egymással HLA-identikusak, egymásnak potenciális donorai a betegség miatt azonban nem lehetnek, ezért két független HLA-identikus idegen donort kerestünk számukra. Az EWOG-MDS nemzetközi akadémiai tanulmány (NCT00662090) résztvevőiként súlyos infekció és hemoszupportáció hiányában „watch and wait” stratégiát alkalmazunk, a gyermekek teljes értékű életet élnek, az esetleges transzplantációra felkészültünk.
A hagyományos genetikai vizsgálatokkal nem azonosítható hajlamosító genetikai variáns további felkutatására MLPA-t használtunk. A vizsgálat során a négytagú családból 3 főnél figyeltünk meg monoallélikus vesztést a 3 q26 genomikus régióban. Az anya DNS-mintájában ezzel a módszerrel nem azonosítottunk eltérést ( $3 A$ ábra). A család többi tagjánál a TERC gén 1-es exonját érintő deléciót találtunk, az MLPA szondakeverékben megtalálható, erre az exonra specifikus összes (4 db) szonda kópiája csökkent relatív kópiaszámot mutatott. A genetikai el- 


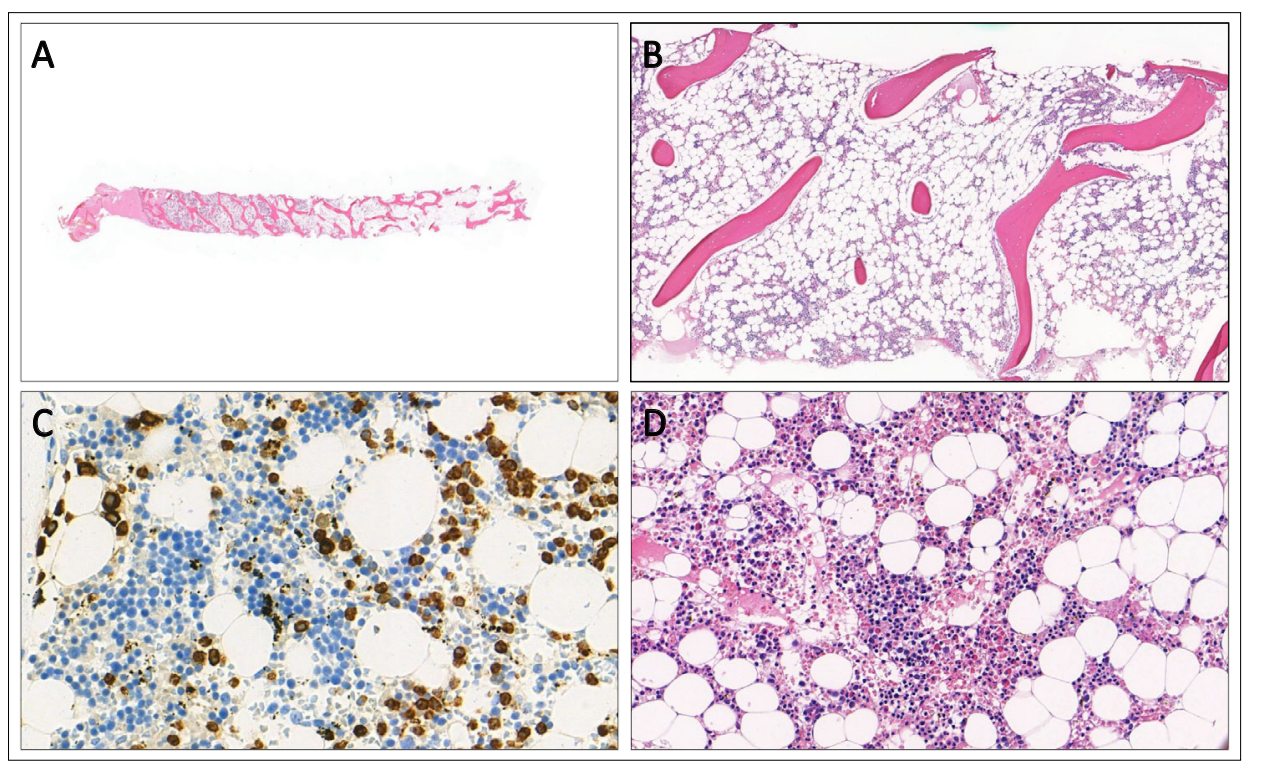

2. ábra. A gyermekek csontvelőbiopsziája a refrakter citopenia jellegzetes képét mutatja. (A) A csontvelőben a vérképző sejtek eloszlása egyenetlen. (B) A szövettani mintában $30 \%$ körüli cellularitás látható. (C) Myeloperoxidázzal festve látható a csökkent mértékü granulopoesis, valamint a myeloiderythroid arány megfordulása a megaloblastos, balratolt erythropoesis javára (hematoxilin háttérfestés). (D) Hematoxilin-eozin festéssel kiterjedt erythroid vérképző szigetek ábrázolódnak. A megakarocyták száma a csontvelő cellularitásához képest is csökkent, köztük CD61-pozitív dysplasticus micromegakaryocyták is jelölődnek

térést már hordozó apánál (3B ábra) nem alakult ki MDS, a monoallélikusan deletált TERC gén nem okozott klinikai tüneteket. A két gyermek ( $3 C$ és $3 D$ ábra) esetében ugyanaz a kópiaszámvesztés látható, mint az apa mintájában. $\mathrm{Az}$ általunk feltárt genetikai eltérés a betegség megjelenése előtt nem okozott klinikai tüneteket, a családban tünet- mentesen jelenlévő monoallélikus TERC-deléció prediszpozíciós szindrómaként a két gyermek esetében de novo MDS kialakulásához vezetett.

A familiáris MDS-re specifikus szondakeverékkel nem találtunk egyéb kiegyensúlyozatlan, DNS-kópiaszám-változással járó eltérést, a vizsgált mintákban a GATA2
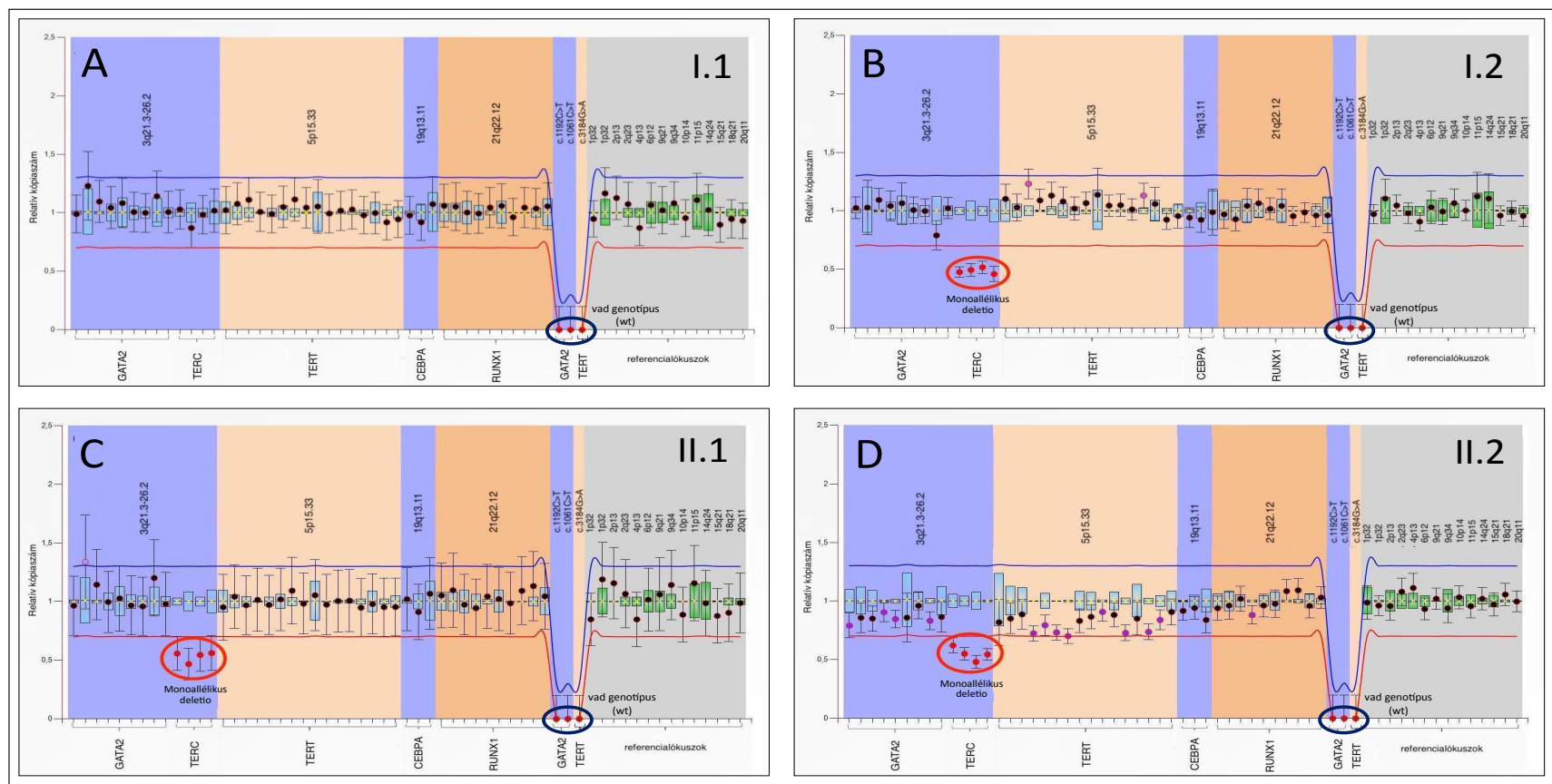

3. ábra. P437-B1 szondakeverékkel kimutatott DNS-kópiaszám-eltérések a vizsgált, familiáris MDS-ben szenvedő családnál. A vízszintes tengelyen az egyes MLPA-szondák, a függőleges tengelyen azok relatív kópiaszáma látható. A vörös és kék vonalak között a normalizálás eredményeként meghatározott normáltartomány helyezkedik el. A kék vonal feletti értékek esetén kópiaszámnyerésről (többlet vagy amplifikáció), a vörös vonal alatt pedig kópiaszámvesztésről (deléció) beszélünk. A négy kópiaszámprofilon láthatók olyan szondák is, melyekről az átíródott kópiák relatív kópiaszáma 0, vagyis a szondával komplementer, adott bázissorrendű DNS-szakasz az eredeti mintában nem volt jelen. Ez a három mutációspecifikus szonda a GATA2 és TERT génekben található pontmutációk detektálására alkalmas. Az eredmények alapján a vizsgált család mindegyik tagja az adott mutációkra [GATA2 (c.1192C > T, c.1061C >T) és TERT (c.3184G<A)] nézve vad genotípusú, a genetikai eltérést nem hordozzák. (A) Az anya (I.1) DNS-mintájában MLPA-val detektálható eltérést nem azonosítottunk. (B) Az apából (I.2) származó mintában a relatív kópiaszámprofilon a TERC gén 1. exonjának monoallélikus deléciója, del(3q) látható. (C) A 16 éves fiú (II.1) mintájából készült kópiaszámprofilon a TERC génnek az apa mintájában látott, hasonló kiterjedésü deléciója figyelhető meg. (D) A tizenkét éves lánytestvér is ugyanazt a genetikai eltérést hordozza, mint a testvére (II.1) és az édesapja (I.2) 
(c.1192C>T, c.1061C>T) és TERT (c.3184G<A) géneket érintő pontmutációk sem voltak megfigyelhetők (3. ábra).

\section{Megbeszélés}

A myelodysplasiás szindróma általában sporadikus megjelenésű, főként az idősebb korosztályt érintő megbetegedés, azonban ritkán családi halmozódást mutató esetek is előfordulnak [2,7]. A familiáris MDS hátterében legtöbbször olyan germline-mutációk állnak, amelyek az érintett génektől függően különböző prediszpozíciós szindrómákat okoznak. Ezek a herediter genetikai eltérések nem mindig vezetnek klinikai szindróma kialakulásához, gyakran tünetmentesek, azonban az MDS rizikófaktoraiként indokolt a vizsgálatuk. A prediszpozíciós szindrómák és a hátterükben álló genetikai eltérések a vizsgálati módszerek fejlődésével egyre gyakrabban kerülnek felismerésre, így a fiatalkori megbetegedések egyre nagyobb részéről derül ki, hogy azok tulajdonképpen familiáris eredetűek. Az új eredmények alapján a fiatalkori MDS-ben szenvedők között sokkal több a germline-mutációt hordozó személy, mint korábban gondoltuk, valamint egyre több gén érintettsége válik ismertté [13, 23, 24]. Mindezek ellenére az érintett családok egy részében továbbra is ismeretlen a betegségre hajlamosító genetikai tényező. A betegségben a néhány bázispárra kiterjedő abnormalitások mellett ismertek DNS-kópiaszám-eltérések is, amelyek hagyományos mutációanalízissel nem detektálhatók, ezért az ilyen esetekben érdemes olyan vizsgálati módszereket is alkalmazni, amelyek a mutációkon kívül a kópiaszám-változások észlelésére is alkalmasak.

Az MLPA egy olyan alternatív vizsgálati módszer, melyben a vizsgált betegségre specifikus szondakeverékkel adott DNS-szakaszokon megjelenő kiegyensúlyozatlan genomikus eltérések (deléciók, amplifikációk) illetve néhány, a betegségben gyakran előforduló pontmutáció specifikusan detektálhatók. Az MLPA-t a genetikai betegségek diagnosztikájában széles körben használják, azonban alkalmazása az onkohematológia területén is hasznos lehet $[25,26]$. Az általunk vizsgált család mintáiban a hagyományos diagnosztikai módszerekkel nem azonosítottunk eltérést, azonban a klinikum alapján egyértelmü volt az MDS családon belüli halmozódása, ezért tovább kerestük a hajlamosító genetikai variánst, melyhez MLPAvizsgálatot alkalmaztunk.

Az MLPA reakcióval monoallélikus deléciót azonosítottunk a 3q26.2 genomikus lókuszon, mely érintette a $T E R C$ gén 1-es exonjánt. A TERC gén a telomeráz reverz transzkriptáz megfelelő müködéséhez szükséges információt kódol, ilyen kiterjedt DNS-szakaszt érintő deléciója a TERT gén érintettségéhez hasonlóan prediszpozíciós szindrómák kialakulását okozza [6]. Ezen gének funkcióvesztő megváltozásai telomeropathiákhoz, ún. „telomere biology disorder” (TBD) kialakulásához vezetnek, melynek talaján dyskeratosis congenita (DC) alakul- hat ki, amely a TBD leggyakoribb formája [27, 28]. Ez a jellegzetes klinikummal járó fenotípus jelentős mértékben növeli a kezelés során kialakuló csontvelö-elégtelenség rizikóját azonban a genetikai variáns a rá specifikus klinikum nélkül prediszpozíciós szindrómaként közvetlenül is növeli az MDS kialakulásának valószínűségét [29-32]. Ebből adódóan a feltárt TBD a rá jellemző fenotípus nélkül is befolyásolhatja a további terápiás döntéseket, mivel kedvezőtlenül befolyásolhatja egy esetleges csontvelötranszplantáció kimenetelét.

A szakirodalomban eddig leírt és a betegségben feltételezhetően szerepet játszó, a TERC gént érintő eltérések túlnyomórészt pontmutációk, vagy kisebb, néhány bázispárt érintő deléciók [23]. Az MLPA-val általunk azonosított monoallélikus del(3q) nagyobb kiterjedésü, a TERC gén egyik teljes exonját érinti. A leírt aberrációk az összes többi, prediszpozíciós szindrómához köthető eltéréshez hasonlóan növelik a familiáris MDS kialakulásának rizikóját, így feltételezhető, hogy az általunk talált kiterjedtebb eltérés is az MDS egyik rizikófaktora.

Az általunk MLPA-val feltárt genetikai eltérés nem tartozik a korábban leírt TBD megbetegedésekben előforduló DNS-abnormalitások közé, azonban valószínűsíthető, hogy az apa és a gyermekek mintájában megjelenő genetikai variáns áll az MDS családi halmozódása hátterében, így a korábbi esetekben leírt variánsokhoz hasonlóan ez az eltérés is prediszpozíciós szindróma kialakulásához vezethet.

Az MLPA-val feltárt monoallélikus TERC gén deléció olyan genetikai eltérés, amely egész életen keresztül növeli az MDS kockázatát. Mivel az eltérést hordozó apa esetében az MDS nem manifesztálódott, valószínüsíthető, hogy a gyerekek betegségében egyéb, az általunk használt módszerrel nem azonosítható, szekunder genetikai abnormalitás is szerepet játszott [28]. A betegség kifejlődéséért triggerként felelős eltérés felkutatása további molekuláris vizsgálatok tárgya lehet, melyek az MLPA-t kiegészítve még részletesebb képet adhatnak a leírt familiáris MDS-ben szenvedő család genetikai hátteréről. A gyermekekben manifesztálódó betegség és az édesapában is jelenlévő TBD miatt megfontolandó lehet a követés kiterjesztése az édesapára, valamint a közeli hozzátartozókra is, hiszen nagy valószínüséggel ők is az MDS-re hajlamosító genetikai variáns hordozói [33].

A vizsgálatban alkalmazott MLPA szondakeverék a familiáris MDS/AML-re specifikus szondákat tartalmazza a GATA2, TERT, TERC, RUNX1 és CEBPA gének vonatkozásában, így használatával a betegségben leggyakrabban előforduló kópiaszám-eltéréseket tudtuk detektálni. Ez a specifikus vizsgálati módszer így megfelelő kiegészítése lehet a standard diagnosztikában használt mutációanalízisnek és használatával a familiáris halmozódást mutató esetekben jelentkező genomikus eltérések eddiginél szélesebb spektruma vizsgálható, ami végeredményben a familiáris myeloid kórképekben szenvedő betegek pontosabb korai azonosításához is hozzájárulhat. 
Nyilatkozat: A kézirat korábban más folyóiratban nem jelent meg, és máshova beküldésre nem került. A levelezőszerző elolvasta a Hematológia-Transzfuziológia szerzői útmutatóját.

Anyagi támogatás: A közlemény megírásához kapcsolódó munkát a Nemzeti Kutatási, Fejlesztési és Innovációs Hivatal - NKFIH, K119950 és NVKP_16-1-2016-0004 és KH17126718 pályázatai, a Magyar Tudományos Akadémia Lendület Programjának LP95021 pályázata, a Magyar Tudományos Akadémia Bolyai János Kutatási Ösztöndíja, az Emberi Erőforrások Minisztériuma ÚNKP-18-4-SE-62 kódszámú Új Nemzeti Kiválósági Programja, valamint az Emberi Erőforrások Minisztériumának Felsőoktatási Intézményi Kiválósági Programja finanszírozta, a Semmelweis Egyetem Molekuláris Biológia tématerületi programja keretében.

Érdekeltségek: A szerzőknek a közleményhez kapcsolódó közvetlen érdekeltségeik nincsenek.

Szerzői munkamegosztás: K. L. és K. R.: A bemutatott tanulmány megtervezése. K. K.: Betegellátás és minták gyüjtése. K. L., K. P., B. Cs., A. D. és K. R.: A kísérletek kivitelezése és értékelése. B. Cs. és A. D.: A tanulmánnyal kapcsolatos vizsgálatok koordinálása és felügyelete. Cs. J.: Szövettani vizsgálatok értékelése. K. L., K. R., A. D. és B. Cs.: A kézirat elkészítése. A cikk végleges változatát valamennyi szerző elolvasta és jóváhagyta.

\section{Irodalom}

[1] Swerdlow SH, Campo E, Harris NL, et al. WHO Classification of Tumours of Haematopoietic and Lymphoid Tissues. 4th ed., eds. F. T. Bosman, et al., 2008, Lyon: International Agency for Research on Cancer. pp. 104-107.

[2] Locatelli F and Strahm B. How I treat myelodysplastic syndromes of childhood. Blood 2018; 131: 1406-1414.

[3] Niemeyer CM and Baumann I. Classification of childhood aplastic anemia and myelodysplastic syndrome. Hematology Am Soc Hematol Educ Program 2011; 2011: 84-89.

[4] Babushok DV, Bessler M, and Olson TS. Genetic predisposition to myelodysplastic syndrome and acute myeloid leukemia in children and young adults. Leuk Lymphoma 2016; 57: 520-536.

[5] Glaubach T, Robinson LJ, Corey SJ. Pediatric myelodysplastic syndromes: they do exist! J Pediatr Hematol Oncol. 2014; 36: 1-7.

[6] Kiraly PA, Kallay K, Marosvari D, et al. [Clinical and genetic background of familial myelodysplasia and acute myeloid leukemia]. Orv Hetil. 2016; 157: 283-289.

[7] Holme H, Hossain U, Kirwan M, et al. Marked genetic heterogeneity in familial myelodysplasia/acute myeloid leukaemia. Br J Haematol. 2012; 158: 242-248.

[8] Akpan IJ, Osman AEG, Drazer MW, et al. Hereditary myelodysplastic syndrome and acute myeloid leukemia: Diagnosis, questions, and controversies. Curr Hematol Malig Rep. 2018.

[9] Feurstein S, Drazer MW, Godley LA. Genetic predisposition to leukemia and other hematologic malignancies. Semin Oncol. 2016; 43: 598-608.

[10] Kiraly AP, Kallay K, Gango A, et al. Familial acute myeloid leukemia and myelodysplasia in Hungary. Pathol Oncol Res. 2018; 24: 83-88.

[11] Owen C, Barnett M, Fitzgibbon J. Familial myelodysplasia and acute myeloid leukaemia - A review. Br J Haematol. 2008; 140: 123-132.

[12] Hong M, He G. The 2016 revision to the World Health Organization classification of myelodysplastic syndromes. J Transl Int Med. 2017; 5: 139-143.

[13] Aleshin AG, L.P. Molecular pathophysiology of the myelodysplastic syndromes: Insights for targeted therapy. Blood Advances 2018 2: 2787-2797.
[14] Tawana K, Wang J, Kiraly PA, et al. Recurrent somatic JAK-STAT pathway variants within a RUNX1-mutated pedigree. Eur J Hum Genet. 2017; 25: 1020-1024.

[15] Liew E, Owen C. Familial myelodysplastic syndromes: a review of the literature. Haematologica 2011; 96: 1536-1542.

[16] Hsu AP, Sampaio EP, Khan J, et al. Mutations in GATA2 are associated with the autosomal dominant and sporadic monocytopenia and mycobacterial infection (MonoMAC) syndrome. Blood 2011; 118: 2653-2655.

[17] Kazenwadel J, Secker GA, Liu YJ, et al. Loss-of-function germline GATA2 mutations in patients with MDS/AML or MonoMAC syndrome and primary lymphedema reveal a key role for GATA2 in the lymphatic vasculature. Blood 2012; 119: 1283-1291.

[18] Both A, Krauter J, Damm F, et al. The hypomorphic TERT A1062T variant is associated with increased treatment-related toxicity in acute myeloid leukemia. Ann Hematol. 2017; 96: 895-904.

[19] Cortes JE, Kantarjian H, O'Brien S, et al. Clinical and prognostic significance of trisomy 21 in adult patients with acute myelogenous leukemia and myelodysplastic syndromes. Leukemia 1995; 9: 115117.

[20] Wang J, Ai X, Qin T, et al. Multiplex ligation-dependent probe amplification assay identifies additional copy number changes compared with R-band karyotype and provide more accuracy prognostic information in myelodysplastic syndromes. Oncotarget. 2017; 8: 1603-1612.

[21] Lukackova R, Gerykova Bujalkova M, Majerova L, et al. Molecular genetic methods in the diagnosis of myelodysplastic syndromes. A review. Biomed Pap Med Fac Univ Palacky Olomouc Czech Repub. 2014; 158: 339-345.

[22] Kiss R, Kosztolanyi S, Gango A, et al. [Multiplex ligation-dependent probe amplification in oncohematological diagnostics and research]. Orv Hetil. 2018; 159: 583-592.

[23] Field JJ, Mason PJ, An P, et al. Low frequency of telomerase RNA mutations among children with aplastic anemia or myelodysplastic syndrome. J Pediatr Hematol Oncol. 2006; 28: 450-453.

[24] Tawana K, Fitzgibbon J. Inherited DDX41 mutations: 11 genes and counting. Blood 2016; 127: 960-961.

[25] Stuppia L, Antonucci I, Palka G, et al. Use of the MLPA assay in the molecular diagnosis of gene copy number alterations in human genetic diseases. Int J Mol Sci. 2012; 13: 3245-3276.

[26] Kiss R, Papp G, Krizsán S, et al. [Screening for genomic copy number alterations in chronic lymphocytic leukemia using multiplex ligation-dependent probe amplification]. Hematológia-Transzfuziológia 2018; 51.

[27] Kirwan M, Vulliamy T, Marrone A, et al. Defining the pathogenic role of telomerase mutations in myelodysplastic syndrome and acute myeloid leukemia. Hum Mutat. 2009; 30: 1567-1573.

[28] West AH, Godley LA, and Churpek JE. Familial myelodysplastic syndrome/acute leukemia syndromes: A review and utility for translational investigations. Ann N Y Acad Sci. 2014; 1310: 111-118.

[29] Bannon SA, DiNardo CD. Hereditary predispositions to myelodysplastic syndrome. Int J Mol Sci. 2016; 17.

[30] Schulz E, Valentin A, Ulz P, et al. Germline mutations in the DNA damage response genes BRCA1, BRCA2, BARD1 and TP53 in patients with therapy related myeloid neoplasms. J Med Genet. 2012; 49: 422-428.

[31] Alter BP, Giri N, Savage SA, et al. Cancer in dyskeratosis congenita. Blood 2009; 113: 6549-6557.

[32] Godley LA, Shimamura A. Genetic predisposition to hematologic malignancies: management and surveillance. Blood 2017; 130: 424-432.

[33] Churpek JE, Lorenz R, Nedumgottil S, et al. Proposal for the clinical detection and management of patients and their family members with familial myelodysplastic syndrome/acute leukemia predisposition syndromes. Leuk Lymphoma. 2013; 54: 28-35. 